\title{
MODEL SISTEM INFORMASI GEOGRAFIS PARIWISATA MENGGUNAKAN REUSE METHOD
}

\author{
Henderi $^{1}$, Andrian Saputra ${ }^{2}$, Didik Setiyadi ${ }^{3}$ \\ Dosen Universitas Raharja ${ }^{1}$, Mahasiswa Universitas Raharja ${ }^{2}$, Dosen Universitas Bina \\ Insani, Bekasi $^{3}$ \\ 1,2 Jalan Jenderal Sudirman No.40 Kota Tangerang \\ ${ }^{3}$ Jalan Siliwangi No.6 Rawa Panjang Kota Bekasi \\ Sur-el : henderi@raharja.info 1, andrian.saputra@raharja.info ${ }^{2}$, \\ didiksetiyadi@binainsani.ac.id ${ }^{3}$
}

\begin{abstract}
Information about tourism sites in Tangerang Regency is inadequate. Tourists have difficulty in obtaining information about tourist attractions. This study propose a model of tourism geographic information system (GIS) to make help tourists to find and obtain information about tourism in Tangerang Regency easier. In this research, activities consist of two stages, namely: data collection and system design. Data collection activities carried out by observation, interviews, and literature study. While the GIS model is designed with Unified Modeling Language, reuse method, and prototype. The final result of this research is a model of tourism geographic information system in the form of use case diagrams, activity diagrams, class diagrams and prototype user interfaces. The test results showing that the model produced has a score of 72.1 with a good predicate. This shows that the resulting model is in accordance with needs and can be used as a basis in building a tourist geographic information system.
\end{abstract}

Keywords: Geographic information system, reuse method

\begin{abstract}
Abstrak : Informasi mengenai tempat pariwisata di Kabupaten Tangerang belum memadai. Wisatawan memiliki kesulitan untuk memperoleh informasi mengenai tempat wisata. Penelitian ini menawarkan model sistem informasi geografis (SIG) pariwisata untuk memudahkan wisatwan mencari dan mendapatkan informasi tentang kepariwisataan di Kabupaten Tangerang. Kegiatan penelitian secara umum terdiri dari dua tahapan, yaitu pengumpulan data dan perancangan sistem. Kegiatan pengumpulan data dilakukan dengan metode observasi, wawancara, dan studi pustaka. Sementara model SIG dirancang dengan metode reuse, Unified Modelling Language, dan prototipe. Hasil akhir penelitian ini adalah sebuah model sistem informasi geografis parawisata yang berbentuk use case diagram, activity diagram, class diagram dan prototipe user interface. Hasil pengujian menunjukan bahwa model yang dihasilkan memiliki skor memiliki skor penilaian 72,1 dengan predikat baik. Model yang dihasilkan sesuai kebutuhan dan dapat dijadikan landasan dalam membangun sistem informasi geografis parawisata.
\end{abstract}

Kata kunci: Sistem informasi geografis, reuse method

\section{PENDAHULUAN}

Dokumen Kabupaten Tangerang memiliki beberapa objek pariwisata yakni wisata alam, wisata buatan, dan wisata budaya serta Hotel. Kabupaten Tangerang memliki pantai dikenal luar oleh masyarakat, diantaranya Pantai Tanjung Pasir dan Pantai Tanjung Kait. Kedua pantai ini cukup bagus untuk dikunjungi setiap hari libur. Selain panoramanya yang cukup bagus, wisatawan juga dapat menikmati wisata kuliner yang berada disekitarnya. Selain itu, Kabupaten Tangerang juga memiliki beberpa objek wisata lain yang potensial dikembangkan. Pada bagian lain, Kabupaten Tangerang belum 
memiliki sistem informasi geografis (SIG) pariwisata.

Saat ini SIG berkembang begitu pesat. SIG dapat digunakan untuk membantu daerah dalam mengembangkan potensi wisata dan membantu para wisatawan. SIG Pariwiasata dapat dikembangkan dan dibuat dengan memanfaatkan data lokasi atau tempat wisata dan hotel yang berasal dari Dinas Pemuda Olahraga, Kebudayaan dan Pariwisata. Data tersebut berupa data tempat wisata dan data lokasi hotel yang ada pada suatu daerah. Berdasarkan pengamatan dan wawancara awal terhadap pihak yang terkait dengan pariwisata, kepariwisataan di Kabupaten Tangerang memiliki beberapa permasalahan. Diantaranya, belum tersedianya sistem informasi yang menyediakan informasi mengenai tempat wisata dan hotel di Kabupaten Tangerang. Akibatnya masyarakat mengalamai kesulitan untuk mencari tempat wisata dan hotel yang tepat untuk dikunjungi.

Berdasarkan permasalahan tersebut, penelitian ini bertujuan menghasilan model SIG pariwisata dan sesuai kebutuhan wisatawan, dan dapat menyediakan informasi tentang tempat wisata dan hotel di Kabupaten Tangerang. Model yang dihasilkan diharapkan dapat dijadikan sebagai acuan dalam menghasilkan aplikasi SIG pariwisata di Kabupaten Tangerang. Model SIG pariwisata pada penelitian ini dikembangkan menggunakan metode Unified Modelling Language (UML), reuse method dan protoyping.

Ada beberapa penelitian tentang sistem informasi geografis dengan berbagai metode. Diantaranya yang menggunakan pendekatan waterfall [1], tentang sistem informasi geografis wisata kuliner. Penelitian lain [2], memiliki persamaan dengan penelitian yang dibahas pada paper ini karena menggunakan google maps API dan platform android. Penelitian lain dan sejenis juga menggunakan Global Positioning System untuk mendapatkan data lokasi objek wisata [3]. Sementara penelitian tentang sistem informasi geografis namun menggunakan pendekatan System Development Life Cycle [4]. Kelompok penelitian ini belum mencantumkan objek hotel sebagai class dalam sistem informasi pariwisata, dan juga belum menerpakan metode reuse.

Laporan penelitian lain merancang sistem informasi menggunakan metode UML [5] Penelitiannya sejenis dengan penelitian yang dibahas pada paper ini, namun belum membahas tentang lokasi pariwisata dan hotel, melainkan lokasi prakerin. Penelitian lain [6], membahas tentang SIG pariwisata di Kota Tangerang untuk memudahkan wisatawan dalam mencari tempat wisata. Penggunaan UML sebagai perancangan aplikasi.

Publikasi lain [8], melaporkan tentang penelitian berbasis android sebagai media untuk mengetahui lokasi pariwisata. Sementara itu, ada juga penelitian yang sejenis yang menggunakan UML dalam merancang sistem dan dibantu dengan prototipe sebagai rancangan tampilan juga dilakukan Karolina et.al [9]. Namun demikian, penelitian [6], [8], dan [9] belum membahas hotel sebagai bagian objek penelitiannya tetapi hanya membahas lokasi wisata.

Sumber berbeda[7], menggunakan metode user centered design dalam pengembangan sistem berbasis web tentang pariwisata. Laporan 
lainnya [10], menyajikan informasi berbasis web untuk mengetahui informasi wisata menggunakan pendakan UML. Namun demikian, di dalam kedua penelitian tersebut belum membahas tentang hotel sebagai media penginapan untuk wisatawan, dan juga belum menerapkan metode reuse dalam pengembangan sistem. Hal ini juga berbeda dengan penelitian lainnya [11], yang menggunakan ArcGIS 10.5 untuk menampilkan data spasial serta paparan data secara deskripsi dan mengaplikasikan informasi objek wisata.

Sementara itu, penelitian sejenis yang menggunakan pendekatan UML dalam membuat desain sistem informasi geografis objek wisata [12]. Metode perancangan sistem sejenis juga terdapat pada publikai yang lain [13], [14]. Namun demikian, pada pada penelitian [11], [12], [13] dan [14] juga belum membahas hotel sebagai objek penelitian. Selain itu, pada kelompok penelitian tersebut juga belum menggunakan metode reuse.

Memperhatikan hasil kajian terhadap literatur yang dilakukan, diketahui bahwa pengembangan model SIG pariwisata yang dibahas pada paper ini penting dilakukan, dan memiliki perbedaan dengan penelitian sebelumnya serta memiliki kebaruan. Perbedaan dan kebaruan tersebut adalah penggunakan metode UML, metode reuse dan prototipe pada tahapan desain. Selain itu, penelitian SIG pariwisata yang dibahs pada paper ini mencantumkan class hotel sebagai bagian dari entitas yang berelasi dengan objek wisata.

\section{METODOLOGI PENELITIAN}

Penelitian ini dilakukan dengan dua tahap. Kegiatan pertama adalah pengumpulan data, dan tahap kedua membuat rancangan sistem. Pengumpulan data dilakukan dengan pendekatan observasi ke Dinas Pariwisata, wawancara dengan pegawai Dinas Pariwisata, dan studi pustaka terhadap buku, jurnal, artikel dan penelitian sebelumnya yang relevan.

Perancangan sistem dilakukan menggunakan metode unified modeling language [15]. Rancangan sistem digambarakan dalam bentuk use case diagram, activity diagram, dan class diagram. Sementara itu, untuk menggamabarkan sistem yang dihasilkan maka prototIpe sistem digambarkan dalam bentuk racangan user interface sistem informasi geografis pariwisata. Kegiatan dan tahapan penelitian secara umum ditunjukan di Gambar 1.

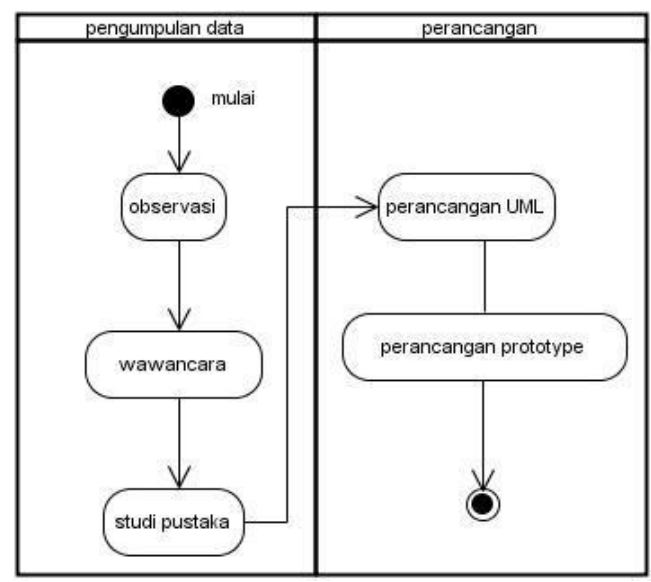

Gambar 1. Diagram Alir Metode

\section{Penelitian}

Selain menggunakan pendekatan UML dan prototipe, model sistem informasi geografis pada penelitian ini juga menggunakan metode reuse [15]. Metode reuse digunakan pada tahapan perancangan. Metode reuse digunakan 
dengan tujuan mempercepat proses desain dan pembuatan aplikasi yang dikembangkan. Hal ini karena metode reuse memungkinkan penggunaan elemen-elemen yang sudah ada pada sistem yang sudah ada dapat digunakan pada sistem yang sedang dikembangkan.

Pada tahap akhir, kegiatan evaluasi terhadap model yang dihasilkan dilakukan dengan pendekatan evaluasi sistem yang diajukan oleh Parmer [18]. Pendekatan ini digunakan dengan alasan bahwa model SIG yang dikembangkan berbasis mobile. Untuk mendapatkan hasil evaluasi yang berfokus terhadap model, maka evaluasi dilakukan terhadap lima aspek model sistem yang dihasilkan. Evaluasi dilakukan dengan cara mengundang perwakilan stakeholder untuk menilai model berdasarkan lima aspek, yaitu: kualitas rancangan, pengaturan informasi, kejelasan navigasi sistem, kegunaan sistem, dan kemudahan penggunaan.

Evaluasi dilakukan dengan metode focus group discussion dan angket penilaian. Setiap perwakilan stakeholder diberikan kesempatan menyampikan penilaiannya terhadap model SIG pariwisata yang dihasilkan, dan mengisi angket penilaian terhadap kelima aspek yang dievaluasi. Setiap aspek penilaian dapat dinilai antara 0 sampai 100. Penilaian dari seluruh perwakilan stakeholder dihitung reratanya. Hasil akhir penilaian ditetapkan menggunakan pendekatan yang diajukan Thomas [19] dengan modifikasi sehingga dapat digunakan pada skala penilaian 0 - 100. Predikat penilaian ditentukan berdasarkan skor: 0 - 24,9 (buruk sekali), 25 - 49,9 (buruk), 50 - 74,9 (baik), dan skor 75 - 100 (baik sekali).

\section{HASIL DAN PEMBAHASAN}

\subsection{Desain Sistem}

Desain sistem informasi geografi pariwisata yang dikembangkan dibuat menggunakan pendekatan UML, reuse dan prototyping. Desain sistem dibuat berdasarkan requirmenet analysis yang dilakukan pada kegiatan analisis. Desain sistem digambarkan dalam bentuk use case diagram, activity diagram dan class diagram.

\subsubsection{Use case Diagram}

Desain sistem informasi geografi pariwisata yang dikembangkan digambarkan dalam bentuk use case diagram. Pada gambar 2, dapat dilihat bahwa SIG pariwisata dapat di akses oleh dua aktor yang berbeda yaitu, Admin sebagai pengelola SIG pariwisata dan wisatawan sebagai pengguna sistem. Di mana jika Admin ingin mengelola SIG harus melakukan login untuk bisa menambahkan menghapus serta mengedit data yang ada. Wisatawan bisa melihat informasi dan lokasi wisata dan hotel yang ada di dalam SIG pariwisata tanpa harus login. Hal ini memudahkan wisatawan dalam memperoleh informasi yang cepat dan tepat. Use case diagram di Gambar 3 sejalan dengan penelitian sejenis [6].

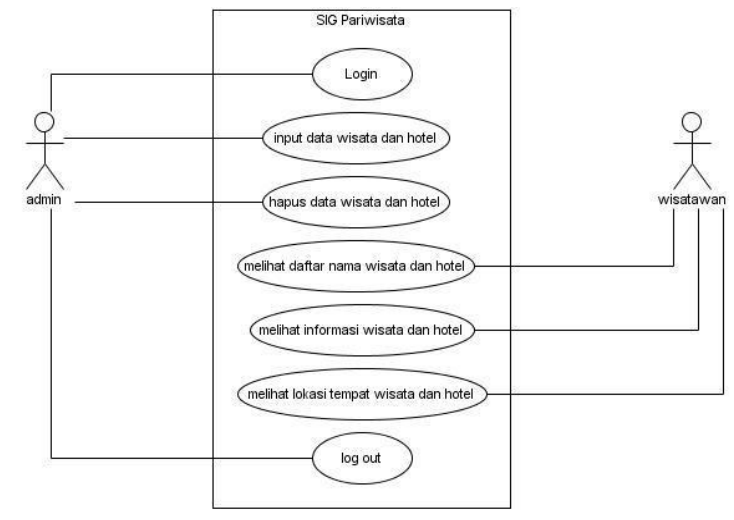

Gambar 2. Use case Diagram SIG Pariwisata 
Use case melihat lokasi wisata dan hotel yang dapat diakses wisatawan pada Gambar 2 merupakan penerapan metode reuse [17]. Use case melihat lokasi pada penelitian ini tidak dibangun secara khusus namun menggunakan use case yang sudah ada pada sistem Global Positioning System (GPS) yang sudah ada sebelumnya.

\subsubsection{Activity Diagram}

Activity diagram menggambarkan aktivitasaktivitas yang dilakukan pengguna ketika menggunakan sistem. Rancangan aktivitas pada sistem informasi geografis yang dikembangkan diilustrasikan dalam bentuk activity diagram di Gambar 3.

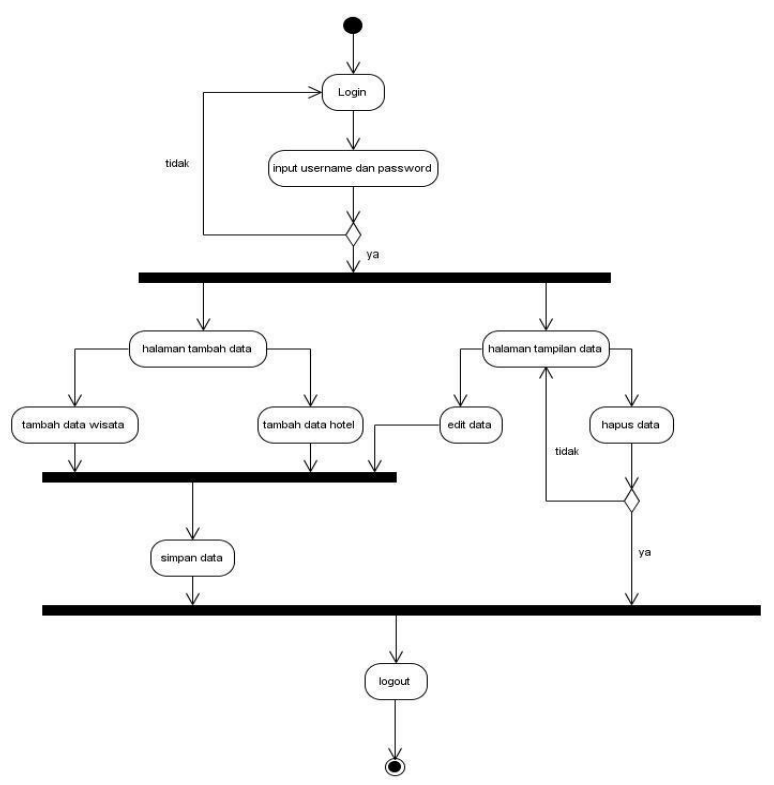

\section{Gambar 3. Activity Diagram SIG Pariwisata}

Gambar 3 menunjukan bahwa pengguna yang ingin mengelola data pada SIG pariwisata harus mempunyai akses dengan cara melakukan login. Admin sebagai super user setelah melakukan login dapat melakukan aktivitas menambah, menghapus, dan mengedit data wisata dan hotel yang ada di dalam sistem. Fungsi login pada SIG disiapkan untuk meminimalisir potensi pencurian data. Dengan demikian, hanya pengguna yang memiliki hak akses yang bisa mengedit data yang ada di dalam sistem. Model activity diagram pada penelitian ini memiliki kesamaan dengan penelitian sejenis [8]. Namun demikian, kedua model ini memiliki perbedaaan, yaitu model activity diagram pada penelitian ini hanya membahas aktivitas admin sebagai pengelola data yang ada pada SIG pariwisata.

\subsubsection{Class Diagram}

Class diagram merupakan suatu atributatribut dan operasi-operasi yang ada pada suatu sistem yang sedang dirancang. Model data sistem informasi geografis yang dikembangkan digambarkan dalam bentuk class diagram.

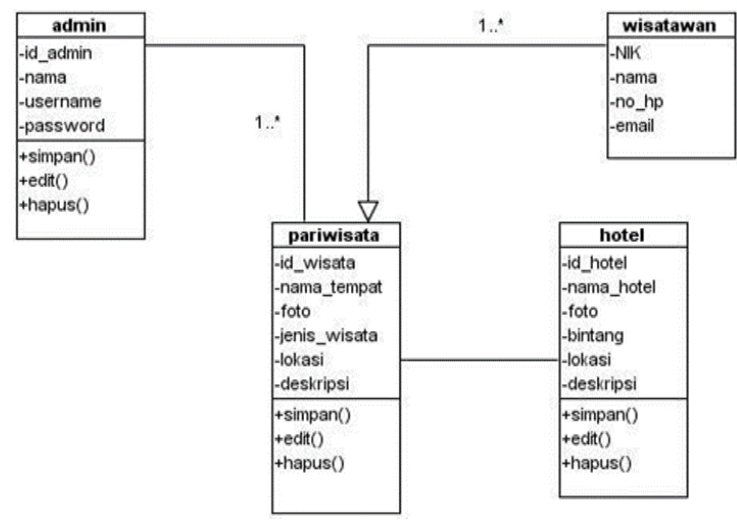

\section{Gambar 4. Class Diagram SIG Pariwisata}

Gambar 4 menunjukan bahwa administrator sistem dapat mengelola data pariwisata dan data hotel. Sementara wisatawan hanya dapat melihat dan mengetahui lokasi pariwisata dan hotel. Model data pada Gambar 5 hampir sama dengan model data yang ada pada penelitian Kurnia et.al [14]. Namun pada model yang dikembangkan pada penelitian ini memiliki objek yang berbeda karena memuat objek hotel sebagai salah satu class. Model data pada Gambar 4 dibuat dengan mengadopsi pendekatan star schema [16]. 
Data di dalam class hotel pada Gambar 4 berasal dari data class hotel yang ada pada sistem informasi hotel yang sudah ada sebelumnya. Penggunaan data class hotel pada sistem informasi geografis parawisata pada Gambar 4 merupakan penerapan metode reuse. Metode reuse merupakan penggunaan elemen-elemen sistem yang sudah ada sebelumnya [17]. Pada penelitian ini, elemen sistem yang sudah ada sebelumnya dan digunakan kembali adalah elemen class hotel. Penerapan metode reuse pada pengembangan SIG pariwisata ini bertujuan mempercepat penyelesaian pembuatan model.

\subsection{Prototipe}

\subsubsection{Tampilan Home}

Halaman home merupakan interface utama sistem yang dikembangkan. Interface home pada Gambar 5 ditampilkan setelah pengguna mengakses SIG pariwisata. Pada halaman home, SIG menampilkan informasi tempat wisata dan hotel popular dan direkomendasikan kepada pengguna. Interface home ini sejenis dengan tampilan home pada penelitian Helmi et.al [13]. Namun terdapat perbedaan karena halaman interface halaman home pada penelitian ini menampilkan tempat wisata dan hotel yang sering dikunjungi oleh wisatawan.

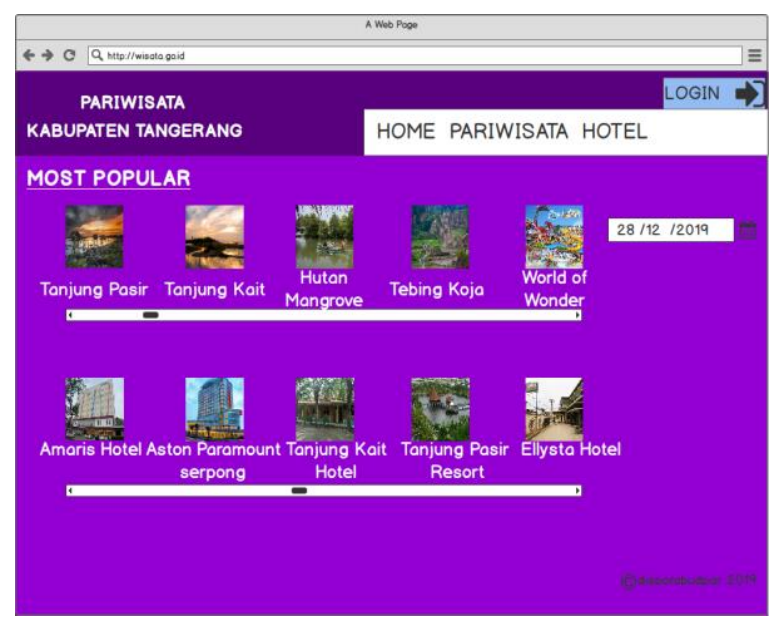

\subsubsection{Interface Pilihan Hotel}

Interface pilihan hotel muncul bila user memilih menu pariwisata untuk mendapatkan informasi wisata dan hotel yang ada di Kabupaten Tangerang. Interface pada Gambar 6 sejenis dengan penelitian sejenis [9], yang menampilkan objek wisata dan hotel yang ada.

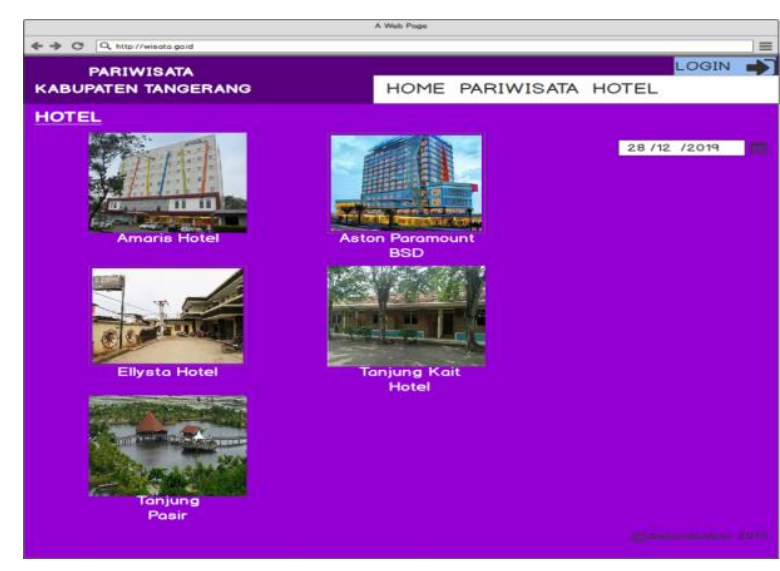

Gambar 6. Halaman Hotel

\subsubsection{Halaman Informasi Objek Wisata}

Halaman informasi ditampilkan ketika pengguna sistem memilih tempat wisata atau hotel. Halaman informasi yang ditunjukan pada Gambar 7 dan berisi deskripsi tempat wisata, hotel, dan tampilan google maps yang menunjukan lokasi secara geografis. Informasi ini sejenis dengan tampilan yang ada pada penelitian Andi et.al [4].

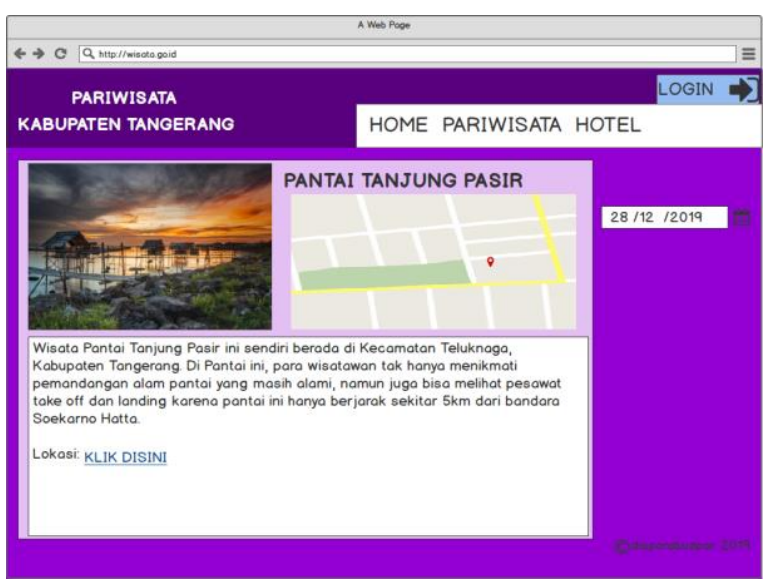

Gambar 7. Halaman Informasi

\section{Gambar 5. Halaman Home}




\subsubsection{Interface Login}

Halaman interface login ditampilkan ketika pengguna mengklik fungsi login pada halaman home. Pengguna harus memasukkan username dan password untuk menggunakan sistem sebagai administrator. Interface login Pada Gambar 8 sejenis dengan login yang ada pada penelitian Kurnia et.al [14]. Namun interface login pada penelitian ini ada gambar khas Kabupaten Tangerang sebagai tempat penelitian dilakukan. Namun demikian hal ini tidak mengurangi fungsi utama interface login.

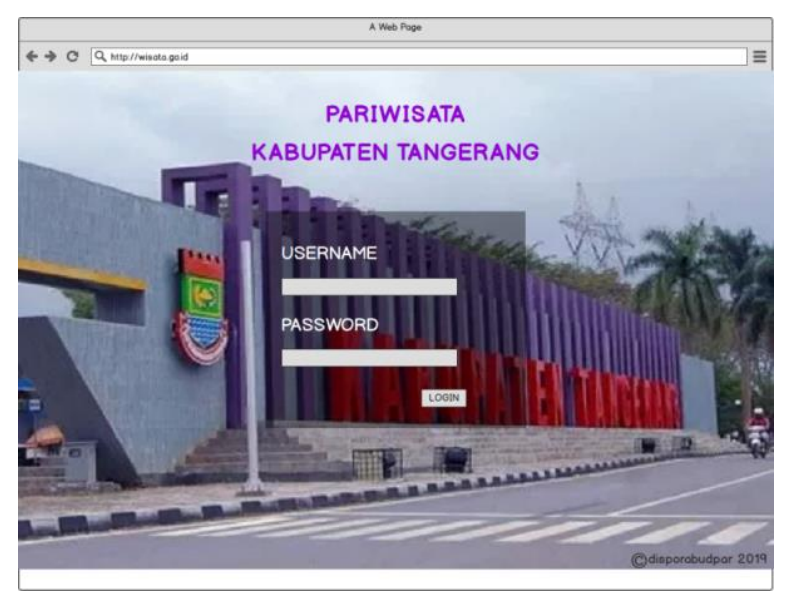

Gambar 8. Tampilan Login

\subsubsection{Tampilan Data Wisata}

Prototipe tampilan data wisata ditunjukan di Gambar 9. User interface pada Gambar 9 menginformasikan bahwa administrator sistem diijinkan melihat data apa saja yang sudah diinput, memilih aksi berupa edit dan hapus data, atau mendambahkan data tempat wisata. Hal ini serupa dengan penelitian [12], namun prototipe pada Gambar 9 lebih sederhana karena menggunakan tabel sebagai media tampilan data wisata dan hotel.

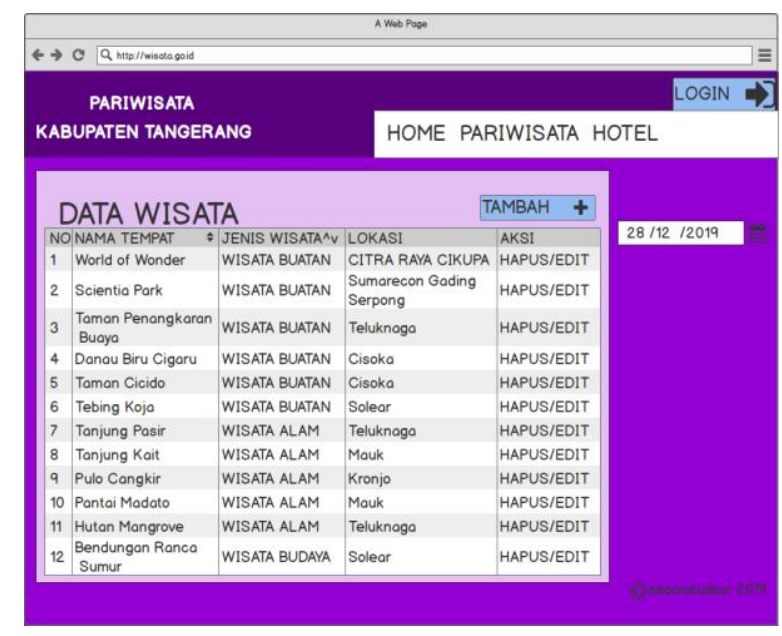

Gambar 9. Tampilan Data Wisata

\subsection{Evaluasi}

Evaluasi terhadap model yang dihasilkan diuji dengan pendekatan focus group discussion yang melibatkan perwakilan stakeholder model SIG yang dikembangkan. Evaluasi ini sejenis dengan yang dilakukan pada aplikasi tentang Covid-19 [20]. Perwakilan stakeholder mewakili unsur pemilik sistem, pakar SIG, pakar model sistem informasi, pelaku industri parawisata, akademisi, dan pengguna akhir SIG yang dikembangkan.

Pemilik sistem diwakili oleh satu orang pegawai Dinas Parawisata, pakar SIG diwakili oleh satu orang pemegang sertifikasi SIG dari BNSP, pakar model sistem informasi diwakili oleh satu orang pemegang sertifikasi analis dan software development dari BNSP, akademisi diwakili oleh dosen pengampu matakulah SIG, dan pengguna akhir diwakili oleh administrator sistem dan satu orang wisatawan. Hasl akhir evaluasi ditunjukan pada Tabel 1. Hasil evaluasi terhadap model SIG yang dihasilkan pada penelitian ini secara keseluruhan diberikan skor 72,1 dengan predikat penilaian baik. 
Tabel 1. Hasil Evaluasi Terhadap Model

\begin{tabular}{llll}
\hline No. & $\begin{array}{l}\text { Aspek yang } \\
\text { dinilai }\end{array}$ & $\begin{array}{l}\text { Rerata } \\
\text { skor }\end{array}$ & $\begin{array}{l}\text { Predikat } \\
\text { penilaian }\end{array}$ \\
\hline 1. & $\begin{array}{l}\text { Kualitas } \\
\text { rancangan }\end{array}$ & 73,2 & Baik \\
2. $\quad \begin{array}{l}\text { Pengaturan } \\
\text { informasi }\end{array}$ & 70,1 & Baik \\
3. $\quad \begin{array}{l}\text { Kejelasan } \\
\text { navigasi sistem }\end{array}$ & 71,4 & Baik \\
4. $\quad \begin{array}{l}\text { Kegunaan } \\
\text { sistem }\end{array}$ & 75,3 & Baik \\
$\quad \begin{array}{l}\text { Kemudahan } \\
\text { penggunaan }\end{array}$ & 72,1 & Baik \\
5. & $\mathbf{7 2 , 4}$ & Baik \\
\hline $\begin{array}{l}\text { Rerata } \\
\text { keseluruhan }\end{array}$ & & \\
\hline
\end{tabular}

\section{KESIMPULAN}

Penelitian ini telah menghasilkan model sistem informasi geografis pariwisata (SIG) menggunakan pendekatan unified modeling language, metode reuse dan protoyping. Model SIG pariwisata digambarkan dalam bentuk use case diagram, activity diagram, class diagram dan prototipe user interface. Model SIG pariwisata yang dihasilkan melalui penelitian ini memiliki skor penilaian 72,1 dengan predikat baik. Model sistem informasi geografis pariwisata pada penelitian ini dapat dijadikan referensi dan acuan dalam membanguan sistem informasi atau aplikasi pariwisata yang mengelola informasi tentang wisata dan hotel, serta memudahkan wisatawan dalam mencari informasi tentang objek wisata.

\section{DAFTAR PUSTAKA}

[1] D. Septian, S. Firdaus, dan E. Kahdar, "Pembuatan Aplikasi Sistem Informasi Geografis Wisata Kuliner Di Kabupaten Garut Berbasis Android" Jurnal Wawasan Ilmiah, Vol.7 No.12, 2015.

[2] W. G. I Wayan, G. D. P. I Ketut, dan S. I Made, "Aplikasi pemetaan objek wisata pantai bali selatan berbasis android" Jurnal Merpati, Vol.4 No.1, 2016.

[3] P. Bambang dan R. MS Khabibur, "Pemanfaatan Sistem Informasi Geografis untuk Pemetaan Wisata Alam dan Budaya sebagai Usaha Perkembangan Kabupaten Sukoharjo" Simposium Nasional RAPI XV, ISSN 1412-9612, 2016

[4] S. Andi, I. P. Ade, dan S. Nana, "Pemetaan Lokasi Wisata di Kota Cirebon dengan Penerapan Aplikasi Sistem Informasi Geografis" Jurnal ICT Vol.18 No.1, 2019.

[5] C. K. Thoullah, A. Bilqisti, dan D. Alifiyanto, "Perancangan Sistem Informasi Geografis (SIG) Sebagai Media Informasi Prakerin Berbasis WEB di SMKN 6 Tangerang Selatan" Jurnal CERITA, Vol.5 No.1, 2019.

[6] S. Sugeng, Ilamsyah, dan Abilaji Rio, "Pandu Lokasi Wisata Kota Tangerang Dengan Sistem Informasi Geografis Berbasis WEB" Jurnal SIMIKA, Vol.2 No.1, 2019.

[7] S. A. Chandra, B. S. Harry, dan B. Indra, "Sistem Informasi Geografis Pariwisata Halal Berbasis Android Dengan Metode Geolocation (Studi kasus: Kota Santri Kabupaten Jombang)" Prosiding SNasTekS, Vol.1 No.1, 2019.

[8] S. Cucut, Hardi dan Mudarsep, "Perancangan Aplikasi Sistem Informasi Geografis Tempat Wisata Di Kabupaten Maros Berbasis Android, Prosiding Seminar Ilmiah Sistem Informasi dan Teknologi Informasi, Vol.8 No.1, 2019

[9] Y. S. Karolina, M. R. M. Natalia, dan B. Patrisius, "Rancang Bangun Sistem Informasi Geogrfis Tempat Pariwisata di Pulau Timor Berbasis WEB" Jurnal Nasional Terindeks SEBATIK, Vol.23 No.21, 2019

[10] V. Nur, A. H. Khairul, dan Muhammad. N., "Sistem Informasi Geografis Wisata Religi Berbasis Web Mobile" Jurnal Sains dan Informatika. Vol.5 No.1, 2019. 
[11] Agus, dan R. Masri, "Pemetaan objek wisata alam kabupaten kepulauan selayar berbasis sistem informasi geografis Arcgis 10.5" Jurnal PUSAKA, Vol.1 No.1, 2019

[12] K. Joni, dan M. Hardi, "Perancangan Sistem Informasi Geografis Lokasi Objek Wisata Di Kota Lubuklinggau Berbasis Android" Jurnal SAKTI, Vol.3 No.2, 2019.

[13] K. Helmi, dan R. T. Muhammad, "Sistem Informasi Geografis Objek Wisata Alam Di Provinsi Sumatera Utara Berbasis Android" Jurnal Ilmiah SISFOTENIKA, Vol.7 No.1, 2017

[14] M. Kurnia, H. Astria, dan Z. Khalida, "Perancangan Aplikasi Desktop Sistem Informasi Geografis (GIS) Penyebaran Wisata Kuliner di Kota Bandar Lampung" Jurnal Komputasi, Vol.2 No.2, 2014.

[15] Padeli, Henderi, Suyatno, "Membangun (EProcurement) Pengadaan Barang dan Jasa Dengan Prinsip Good Corporate Governance Dengan Visual UML" Creative Communication and Innovative Technology Journal, Vol. 2 No. 1, pp. 69-79, 2008

[16] Henderi, H. Indri, dan D. A. Meta, "Business Intelligence Developmeng Model Using Star Schema Methodology" Creative Communication and Innovative Technology Journal, Vol. 5 No. 3, pp. 233-250, 2012

[17] Sommerville, I., "Software Engineering" 9th ed. America: Pearson Education, Inc, 2002.

[18] Palmer, J. W., "Web Site Usability, Design, and Performance Metrics" Information Systems Research, 13(2), 151-167, 2002.

[19] Thomas, V., Salze-Lozac'h V., Kolkma W. dan Ahmed F., "Guidelines for the Evaluation of Public Sector Operations, Independent Evaluation Department" Asian Development Bank, 2019

[20] Henderi, Arigo, Harco Lesli Hendric S Warnars, Didik Setiyadi, and Prima Dina Atika "A mobile application monitoring and decision support systems for diagnosis of Covid-19" Journal of Advanced Research in Dynamical and Control Systems (JARDS), 12(6) pp. 2127-2136. 